\title{
An Assessment of Organizational Factors in Lean Implementation in Apparel Export Units of National Capital Region
}

\author{
Prabhjot Kaur $^{1}$, Kavita Marriya ${ }^{2}$ Radha Kashyap $^{3}$ \\ ${ }^{1}$ Department of Clothing \& Textiles, Government Home Science College, Sector-10, Chandigarh (U.T), 160011, India \\ ${ }^{2}$ Department of Clothing \& Textiles, Government Home Science College, Sector-10, Chandigarh (U.T), 160011, India \\ ${ }^{3}$ Department of Fashion \& Textile Technology, The IIS University, Jaipur(Rajasthan), India
}

\begin{abstract}
Lean manufacturing has caught the attention and imagination of few progressive apparel export-oriented manufacturers in India. Few apparel manufacturing units of National Capital Region (NCR) have started the journey generating a whole lot of success stories with big difference in terms of delivering real business profits and performances, while others are still hesitant and struggling in their traditional setup. As lean is all about bringing operational, organizational learning and cultural change in the manufacturing environment of an organization, it is very important to have an understanding of the organizational factors responsible for its smooth implementation. This study examined the driving factors which brought about changes; barriers which slowed the implementation process; and other critical success factors in bringing about a complete transformation. The top driving factor identified was maintain competitive advantage in service, quality and price; most important lean inhibiting factor was short term focus and lack of consistency; and management support was found to be the most important critical success factors responsible for proper and smooth implementation of lean.
\end{abstract}

Keywords: Lean driving factors, Inhibiting factors, Critical success factors

\section{Introduction}

"Lean is a 'way of working' towards the elimination of waste. It requires transition of behavior and methodology that may be deep rooted within an organization. When an organization chooses to go lean, it also stirs the entire system "[26]

Lean is a pursuit to manufacturing perfection. The journey of an organization to perfection is never ending, but, is full of rewards. With the decision of an organization to initiate the lean process, comes the challenge of bringing about the change in the thought process of their employees and environmental culture. As, it is very important for the apparel manufacturing units initiating lean, to understand the barriers and resisting forces in order to be prepared in advance and succeed in the implementation process of the continuous improvement manufacturing philosophy. This study was planned with the aim of assessing organizational factors important for the systematic implementation of lean process in the journey of apparel units towards perfection.

\section{Literature Survey}

Various critical factors that constituted the successful lean implementation within manufacturing industries were identified in a study which involved use of comprehensive literature review and visit to 10 small and medium scale units based in the East of the UK in order to highlight the degree of lean manufacturing utilization within these companies. Leadership, management, finance, organizational culture, skills and expertise were found to be the most critical factors for the successful adoption of lean manufacturing within small and medium sized firms [2].

A research using survey and case study method was conducted to determine the impact of world-class manufacturing practices on the operational performance of small manufacturers. It was found that the lean practices with the guidance of lean philosophies and principles had a positive impact on the operational performance of smallscale manufacturers in terms of $39 \%$ increase in productivity and $7 \%$ increase in profit. Important barriers identified while lean initiation were untrained unskilled work force with poor work ethics, breaking down old habits, size and age of company, manpower, time, lack of interest, contract manufacturing and old-style management[12].

This research was an attempt to overcome the research gaps found after review of literature by investigating various lean organizational factors specific to the Indian apparel firms.

\section{Methodology}

Field visits to 10 lean- initiated apparel manufacturing units in National Capital Region and in-depth interview with Industrial Engineers was carried out. Cooperation offered and interest shown by the units to participate was the main criterion to select the sample. Various driving, inhibiting and critical success factors in terms of initiation of lean manufacturing system were rated on the scale from unimportant to very important and top five factors were chosen for further statistical analysis using One Way ANOVA test. 


\section{Results and Discussions}

\subsection{Driving Factors}

Rating of driving factors responsible for motivating the apparel units to initiation lean manufacturing system revealed that the factor 'maintain competitive advantage in service, quality and price' scored the highest rating of 4.20 followed by 'pressure to improve profit' with an average of
3.70, 'achieve shorter lead times' with an average of 3.00 , and 'search for best manufacturing practices' with an average of 2.80. The lowest in rating was the factor 'desire to minimize capital blocked in inventory' which scored an average of 1.80. Highly significant p-value of ANOVA $(\mathrm{F}(4,45)=16.51, \mathrm{p}=0.000 * * *)$ demonstrated that the most important driving factor was to gain competitive advantage in service, quality and price(Table 1).

Table 1: Mean, Standard deviation, and Analysis of Variance of Driving Factors in Lean Initiated Apparel Units

\begin{tabular}{|c|c|c|c|c|c|c|c|c|}
\hline \multirow[t]{2}{*}{ Driving Factors } & \multirow[t]{2}{*}{$\mathrm{M}$} & \multirow[t]{2}{*}{ SD } & \multicolumn{2}{|c|}{$\mathrm{df}$} & \multicolumn{2}{|c|}{ Mean Square } & \multirow[t]{2}{*}{ F-value } & \multirow[t]{2}{*}{ p-value } \\
\hline & & & $\begin{array}{c}\text { Between } \\
\text { Groups }\end{array}$ & $\begin{array}{c}\text { With } \\
\text { in Groups }\end{array}$ & $\begin{array}{c}\text { Between } \\
\text { Groups }\end{array}$ & $\begin{array}{l}\text { Within } \\
\text { Groups }\end{array}$ & & \\
\hline $\begin{array}{c}\text { Maintain competitive advantage in } \\
\text { service, quality and price }\end{array}$ & 4.20 & .63 & \multirow[t]{5}{*}{4} & \multirow[t]{5}{*}{45} & \multirow[t]{5}{*}{8.40} & \multirow[t]{5}{*}{.51} & \multirow[t]{5}{*}{16.51} & \multirow[t]{5}{*}{$.000 * * *$} \\
\hline Pressure to improve profit & 3.70 & .82 & & & & & & \\
\hline Achieve shorter Lead times & 3.00 & .67 & & & & & & \\
\hline $\begin{array}{c}\text { Desire to minimize capital blocked in } \\
\text { inventory }\end{array}$ & 1.80 & .63 & & & & & & \\
\hline $\begin{array}{l}\text { Search for best manufacturing } \\
\text { practices }\end{array}$ & 2.80 & .789 & & & & & & \\
\hline
\end{tabular}

Note. $\mathrm{df}=$ Degree of freedom; $\mathrm{F}=$ Anova value. $\mathrm{p}$-value $<0.001=* * * . \mathrm{p}$-value $<0.01=* * \cdot \mathrm{p}$-value $<0.05=* \cdot \mathrm{p}$-value $>0.05=\mathrm{ns}$.

Wheatly,2005 [3] and Nordin [21]also identified improving profit and desire to employ world best practice to the company as important factors which had motivated the units to bring about lean initiations in various organizations.

\subsection{Inhibiting Factors}

Statistical analysis of Lean inhibiting factors in Table 2 revealed that 'short term focus and lack of consistency' was the most prominent inhibiting factor with the mean of 4.60 followed by other factors such as 'lack of resources, employee's resistance to change' and 'lack of understanding and knowhow for implementation'. The lowest in rating was the factor 'lack of management support' with mean of 1.50. One Way ANOVA revealed that the difference between the mean of all the factors was highly significant $\left.\mathrm{F}(4,45)=75.47, \mathrm{p}=0.000^{* * *}\right)$. All the apparel units surveyed had implemented lean with the 'continuous pressure and motivation from top management'; hence it was considered the least rated factor. 'Short term focus' and 'lack of consistency' was the highest rated factor as most of changes started with lot of enthusiasm in most of the apparel units but with time, it wore off and most employees reverted back to the old ways of working probably because they were given additional responsibility in terms of lean implementation. Similar result was found by Dalgobind and Anjani[5] and Kumar \& Naidu[17].

'Lack of resources' in terms of finance, committed team workers or time was found to be the second most important inhibiting factor in smooth implementation of the lean .This may be due to the fact that most of the workers were busy firefighting, working towards sending shipments on time thus, leaving very less time to concentrate on lean trainings.
Dalgobind and Anjani[5];Johnson[12] also found out that the employees were given an additional assignment of championing these programs along with their normal jobs due to lack of capital and human resources. Moreover, most of the companies were not willing to dedicate money and resources to drive the lean thinking efforts. Along with it, there was difficulty in finding appropriate time to conduct training and implement the programs.

The unit managers revealed that the employees, who had been with the company long, had their own set method of working, hence, were reluctant to change. But with the help of training and realization of the benefits, their attitude slowly changed. Similar results were found in various studies which concluded that production managers and line supervisors were generally working with outdated systems, and were reluctant to learn new techniques as changing of old habits and large batch mentality was really difficult[12,13,27 \& 30]. Workers also offered resistance and were generally inflexible in their attitude to accept any new improvement philosophy. Another study also found out that the resistance from employees was due to the fear factor that they would lose their jobs if the unit found out that their jobs do not add value to the product[17] .

It also came to light that 'lack of understanding and knowhow for implementation' was most common among the managers as even though they had undergone tools and techniques training, they were not experts as creating real understanding takes much longer than most manager's plan for. Few studies also identified 'lack of lean understanding', 'lack of adequate communication' and 'middle management attitude' as important inhibiting factors [3,7,21,23 \& 29]. 


\section{International Journal of Science and Research (IJSR) \\ ISSN (Online): 2319-7064}

Index Copernicus Value (2013): 6.14 | Impact Factor (2015): 6.391

Table 2: Mean, Standard deviation, and Analysis of Variance of Inhibiting Factors in Lean Initiated Apparel Units, N=10

\begin{tabular}{|c|c|c|c|c|c|c|c|c|}
\hline \multirow[t]{2}{*}{ Inhibiting Factors } & \multirow[t]{2}{*}{$\mathrm{M}$} & \multirow[t]{2}{*}{ SD } & \multicolumn{2}{|c|}{ df } & \multicolumn{2}{|c|}{ Mean Square } & \multirow[t]{2}{*}{ F-value } & \multirow[t]{2}{*}{ p-value } \\
\hline & & & $\begin{array}{c}\text { Between } \\
\text { Groups }\end{array}$ & $\begin{array}{l}\text { Within } \\
\text { Groups }\end{array}$ & $\begin{array}{c}\text { Between } \\
\text { Groups }\end{array}$ & $\begin{array}{l}\text { Within } \\
\text { Groups }\end{array}$ & & \\
\hline Lack of resources & 4.2 & 0.42 & \multirow[t]{5}{*}{4} & \multirow[t]{5}{*}{45} & \multirow[t]{5}{*}{18.28} & \multirow[t]{5}{*}{0.24} & \multirow[t]{5}{*}{75.47} & \multirow[t]{5}{*}{$.000 * * *$} \\
\hline $\begin{array}{l}\text { Lack of understanding and Knowhow for } \\
\text { implementation }\end{array}$ & 2 & 0.47 & & & & & & \\
\hline Lack of Management Support & 1.5 & 0.58 & & & & & & \\
\hline Employee's Resistance to change & 3.4 & 0.57 & & & & & & \\
\hline Short term focus and Lack of Consistency & 4.6 & 0.52 & & & & & & \\
\hline
\end{tabular}

Note. $\mathrm{df}=$ Degree of freedom; $\mathrm{F}=$ Anova value. $\mathrm{p}$ value $<0.001=* * *$. p-value $<0.01=* * . \quad \mathrm{p}$-value $<0.05=* . \quad \mathrm{p}-$ value $>0.05=\mathrm{ns}$.

\subsection{Critical Success Factors}

Assessment of top five critical success factors as rated by the lean initiated apparel units highlighted that 'Management Support' was the most important critical success factor responsible for proper and smooth implementation of lean with an average mean of 4.20.It was followed by 'trainings and competent lean consultant'. Lowest score was obtained by 'organizational culture of effective communication and continuous improvement' and 'employee involvement and empowerment' with average mean 2.60. One Way ANOVA revealed a highly significant difference in the $\left(\mathrm{F}(4,45)=27.36, \mathrm{p}=0.000^{* * *}\right)$ mean of various critical success factors as shown in Table 3.

'Management support and push' was found to be the most important factor as lean implementation would never work if the management was not clear about the concept and it did not motivate and execute it throughout the apparel unit. Few researches concluded that getting commitment from top level executives was very important for the success of implementing lean manufacturing techniques. The lean manufacturing efforts would fail, if the leaders do not demonstrate commitment and support the initiative by creating interest and communicating the benefits to all its employees [2,3,9,11,13,15,19,22\&25]. Another research highlighted the importance of solid leadership by communicating the vision; setting the standards; assisting the workforce in adapting to the change; building trust and inspiring commitment; and constantly challenging the system [20].

'Comprehensive training schedules' covering technical, managerial and soft skills were found very important, as successful implementation of lean production relies on welltrained working towards common goal focusing on enhancement of the employee skills and motivated embracement of the changes in future. Importance of training was also emphasized in few researches concluded by stating the fact that the units which allots greater resources for the training of the workforce, result in creating continuous improvement environment and further leads to increased productivity[1,3,4,14,18,21 \& 15].

Table 3: Mean, Standard deviation, and Analysis of Variance of Critical Success Factors in Lean Initiated Apparel Units,

\begin{tabular}{|c|c|c|c|c|c|c|c|c|}
\hline \multicolumn{9}{|c|}{$\mathrm{N}=10$} \\
\hline \multirow[t]{2}{*}{ Critical Success Factors } & \multirow[t]{2}{*}{ M } & \multirow[t]{2}{*}{ SD } & \multicolumn{2}{|c|}{$\mathrm{df}$} & \multicolumn{2}{|c|}{ Mean Square } & \multirow{2}{*}{$\begin{array}{c}\text { F- } \\
\text { value }\end{array}$} & \multirow[t]{2}{*}{ p-value } \\
\hline & & & $\begin{array}{c}\text { Between } \\
\text { Groups }\end{array}$ & $\begin{array}{l}\text { Within } \\
\text { Groups }\end{array}$ & $\begin{array}{c}\text { Between } \\
\text { Groups }\end{array}$ & $\begin{array}{l}\text { Within } \\
\text { Groups }\end{array}$ & & \\
\hline Management support & 4.2 & 0.63 & \multirow[t]{5}{*}{4} & \multirow[t]{5}{*}{45} & \multirow[t]{5}{*}{6.08} & \multirow[t]{5}{*}{0.22} & \multirow[t]{5}{*}{27.36} & \multirow[t]{5}{*}{$.000 * * *$} \\
\hline $\begin{array}{l}\text { Organizational Culture of effective } \\
\text { Communication and Continuous Improvement }\end{array}$ & 2.6 & 0.52 & & & & & & \\
\hline Trainings & 4 & 0 & & & & & & \\
\hline Competent Lean Consultant & 3.8 & 0.43 & & & & & & \\
\hline Employee involvement and empowerment & 2.6 & 0.52 & & & & & & \\
\hline
\end{tabular}

Note. $\mathrm{df}=$ Degree of freedom; $\mathrm{F}=$ Anova value. $\mathrm{p}$-value $<0.001=* * * . \mathrm{p}$-value $<0.01=* *$. $\mathrm{p}$-value $<0.05=. \mathrm{p}-\mathrm{value}>0.05=\mathrm{ns}$.

Low score in 'organizational culture of effective communication and continuous improvement' depicted that the units had not incorporated it. Few researches also identified it as playing a crucial role in ensuring the successful implementation of leanness. It was reported by these researches that the company can increase their degree of adoption of lean manufacturing by putting efforts into the nine principles especially the continuous improvement [8,23,24 \& 28].

Most of the lean initiated apparel units revealed that 'competent consultants' was one of the keys to the success of lean implementation as they are the ones that align the changes with the vision of the management and meet its requirements within an affordable budget. Few studies also concluded that good consultants are important as the process of learning lean is like a driving a car. People need to do classroom education and then need to do behind the wheel training before you can go on your own. A consultant guides in carrying out the diagnostics of the organization in the first stages of the process, identifying the bottlenecks and use this improvement opportunity for successfully implementation of lean[3,16,24 \& 31].

'Employees involvement and empowerment' was also identified as important for the success in the process of lean implementation as it was believed that fully aware employees want improvement for themselves irrespective of management support, the involvement of the employees in

\section{Volume 5 Issue 6, June 2016 www.ijsr.net}




\section{International Journal of Science and Research (IJSR) \\ ISSN (Online): 2319-7064}

Index Copernicus Value (2013): 6.14 | Impact Factor (2015): 6.391

all aspects of the project with intense communication and mutual trust embark on the lean transformation process[1,3,6 \& 21].

\section{Conclusion}

The top main driving factors identified for motivating apparel units to initiate the lean implementation were maintain competitive advantage in service, quality and price , pressure to improve profit, achieve shorter lead times , search for best manufacturing practices and desire to minimize capital blocked in inventory. Most important lean inhibiting factors analyzed which act as a barrier and further slows the lean initiation process in an apparel manufacturing unit were short term focus and lack of consistency, lack of resources, employee's resistance to change, lack of understanding and knowhow for implementation and lack of management support. Trainings, management support, competent lean consultant, organizational culture of effective communication and continuous improvement, and employee involvement and empowerment were found to be the most important critical success factors responsible for proper and smooth implementation of lean.

\section{Future Scope}

A longitudinal in-depth study could be conducted to understand the multi-dimensional effects and benefits of lean in the Indian garment industry.

\section{References}

[1] Abdullah, F.M. (2003).Lean manufacturing tools and techniques in the process Industry with focus on steel (Doctoral Dissertation, The University of Pittsburgh, Pittsburgh, PA). Retrieved from http://dscholarship.pitt.edu/7968/1/Abdullah.pdf

[2] Achanga, P.C., Shehab, E., Roy, R., \& Nelder, G. (2004). Critical success factors for lean implementation within SMEs. Journal of Manufacturing Technology Management, 17 (4),460 - 471.Retrieved from www.emeraldinsight.com

/journals.htm? articleid $=1550283 \&$ show $=p d f$

[3] Ahrens, T. (2006). Lean production: Successful implementation of organizational change in operations instead of short term cost reduction efforts. Retrieved from

www.leanalliance.com/en/images/pdf/la_lean_survey.pdf

[4] Boyer, K.K. (1996). An assessment of managerial commitment to lean production. International Journal of Operation \& Production Management, 16 (9), 48 59.

[5] Dalgobind, M., \& Anjani, K. (2009). The effect of lean manufacturing on product quality and industrial productivity: An empirical survey. Advances in Production Engineering and Management,4 (4), 221232.Retrieved from maja.unimb.si/files/APEM/APEM4-4_221-232.pdf

[6] Duque, \& Cadavid. (2007). Lean manufacturing measurement: The relationship between lean Activities and lean metrics. Estudios Gerenciales, 23(105), 69-83.
Retrieved

from

http://www.redalyc.org/pdf/212/21210504.pdf

[7] Farhana, F., \& Amir, A. (2009). Lean production practice: the differences and similarities in performance between the companies of Bangladesh and other countries of the world. Asian Journal of Business Management, 1(1),32-36.Retrieved from http://maxwellsci.com/print/ajbm/32-36.pdf

[8] Gamage , K.G.D.A.S., Piyanka , W.P.G.T. , Jayathilake , L.P.C.B. , Perera, H.S.C., \& Gamage, J.R. (2012 , September 10-11).Challenges and potential impact of applying lean manufacturing techniques to textile knitting industry: A case study of a knitting factory in Sri Lanka. Paper presented at the 3rd International Conference on Engineering, Project and Production Management (EPPM), Brighton, United Kingdom. Retrieved from http://www.ppml.url.tw/EPPM/conferences/2012/downi oad/SESSON3_B/41\%20E131.pdf

[9] Goforth, K.A. (2007). Adapting lean manufacturing principles to the Textile industry (Master's thesis, North Carolina State University, Raleigh, NC). Retrieved from http://repository.lib.ncsu.edu/ir/bitstream/1840.16/2865/ 1/etd.pdf

[10] Gomes, D.M.G. (2012) .Lean manufacturing and the garment industry: A case study (Master's thesis, University of Porto, Porto, Portugal). Retrieved from http://paginas.fe.up.pt/ ee07219/team/

[11] Hallam, C.R.A. (2003). Lean enterprise self-assessment as a leading indicator for accelerating transformation in the aerospace industry (Doctorate Dissertation, Massachusetts Institute of Technology, MA). Retrieved from http://lean.mit.edu/downloads/cat_view/75theses/328-2003-theses

[12] Johnson, D.K. (n.d.). The impact of world-class manufacturing practices on small manufacturers. Retrieved from http://www.value-added-resources.com/ thesis/thesis007.php

[13] Jozaffe, L. B. (2006). Implementing lean manufacturing to improve production efficiency in the manufacturing operations at the Aspen general facility (Master's Thesis, Nelson Mandela Metropolitan University, Port Elizabeth, South Africa). Retrieved from dspace.nmmu.ac.za:8080/ Dissertation\%20final\%20draft.pdf

[14] Karekatti , C.(2013).World -class systems for apparel manufacturing. The Indian Textile Journal, 123(5),8387.

[15]Kotter, J.R. (2007). Leading change - Why transformation efforts fail. Harvard Business Review, $85(1), 96$.

[16] Kovacheva, A.V. (2010). Challenges in lean implementation: Successful transformation towards lean enterprise (Master's Thesis, University of Aarhus, Aarhus, Denmark). Retrieved from http://pure.au.dk/portal-asbstudent/files/9093/ak83188...pdf

[17] Kumar, C.S.C., \& Naidu, N.V.R. (2012, July 11-13). A survey on awareness of lean manufacturing concepts in Indian garment manufacturing industries. N.V.R. Naidu, B. Janakiram, P.V. Raveendra, G.N.M. Babu, S.N. Reddy, \& M. Rajesh (Eds.),Challenges and 


\section{International Journal of Science and Research (IJSR) \\ ISSN (Online): 2319-7064}

Index Copernicus Value (2013): 6.14 | Impact Factor (2015): 6.391

Opportunities in Mechanical Engineering, Industrial Engineering and Management Studies. Proceedings of the International Conference of the Departments of Mechanical Engineering, Industrial Engineering \& Management, and Management studies .Bangalore , India. Retrieved from http://conference.bonfring.org/ proceedings

content/ contents_msr_iccomim_v3_2012.pdf

[18] Mehta, R. K., Mehta, D., \& Mehta, N. K. (2012). An exploratory study on implementation of lean manufacturing practices (with special reference to automobile sector industry). Yönetim ve Ekonomi, 19(2),289-299 .

[19] McGrath, W. (2007).Impact analysis of large-scale lean manufacturing initiatives upon manufacturing process innovation in Irish companies( Master's thesis, Waterford Institute of Technology, Waterford, Ireland). Retrieved from http://repository.wit.ie/974/1/Impact_Analysis_of_Larg e-Scale_Lean_

Manufacturing_Initiatives_upon_Manufacturing_proces s_innovation_in_Irish_Companies.pdf

[20] McGivern, M.H., \& Stiber, A.(n.d.).Lean manufacturing techniques. Retrieved from https://www.ddiworld.com/.../leanmanufacturingtechniq ues_wp_ddi.pdf?

[21] Nordin, N., Deros, B.M., \& Wahab, D.A. (2010). A survey on lean manufacturing implementation in Malaysian automotive industry. International Journal of Innovation, Management and Technology, 1(4), 374380.

[22] Prasad, R.V., Sreenivasa, K.V., \& Srinivas, T.R. (2008). Implementation of a lean model for carrying out value stream mapping in a manufacturing industry. Journal of Industrial and Systems Engineering, 2(3), 180-196.

[23] Puvanasvaran, P., Megat, H., Hong, T.S., \& Razali, M.M. (2009). The roles of communication process for an effective lean manufacturing implementation. Journal of Industrial Engineering and Management, 2(1), 128-152.

[24] Ray,B., Riply,P.,\& Neal,D.(2006). Lean Manufacturing - A systematic approach to improving productivity in the precast concrete industry. PCI Journal,51(1),6271.Retrieved from http://wiki.iricen.gov.in/ doku/ lib/ exe/ fetch.php? media=old_journals_published_by_iricen:track_june20 06.pdf

[25] Stotz, D. (2010, May-June). Lean production in the RMG industry. Textile today: A comprehensive publication of textile and apparel industry. Retrieved from www.textiletoday.com.bd/magazine/43

[26] Tecknopak. (2011).Lean manufacturing - The way to manufacturing excellence. Outlook, December. Retrieved from www.technopak.com/ files/ Apparel_Outloook_2012.pdf

[27] Thomas, R. (2008, October).Performance assessment of apparel industries: Process and tools for enhancing competitiveness. Gurgaon, Haryana, India: Method Apparel Consultancy India Pvt. Ltd. Retrieved from http://www.methodsapparel.com/download/Performanc
e\%20Assessment\%20of\%20Appare1\%20IndustriesA\%20Survey.pdf

[28] Worley,J.M.,\& Doolen, T.L.(2006).The role of communication and management support in a lean manufacturing implementation. Management Decision, 44(2), $228-245$.

[29] Wong, Y.C., Wong, K.Y., \& Ali, A.(2009). A study on lean manufacturing implementation in the Malaysian electrical and electronics industry. European Journal of Scientific Research,38 (4),521-535. Retrieved from http://masdukiasbari.files.wordpress.com/2011/04/ejsr_ 38_4_01.pdf

[30] Wong, Y.C., \& Wong, K.Y. (2011). Approaches and practices of lean manufacturing: The case of electrical and electronics companies. African Journal of Business Management,5 (6), 2164-2174. doi: 10.5897/AJBM10.404

[31] Yamashita, K. (2004).Implementation of lean manufacturing process to xyz company in Minneapolis area (Master's thesis, University of Wisconsin-Stout, Menomonie, WI). Retrieved from www2.uwstout.edu/ content/lib/ thesis/2004/2004yamashitak2.pdf

\section{Author Profile}

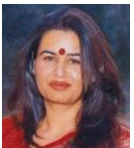

Dr. Prabhjot Kaur received the B.Sc. and M.Sc.(Clothing \& Textiles) degrees from Panjab University, Chandigarh in 1993 and 1998 and PH.D.( Fashion \& Textile Technology ) from The IIS University, Jaipur in 2014. She is Assistant Professor in the Department of Clothing \& Textiles, Government Home Science College, Chandigarh having a teaching experience of 16 years.

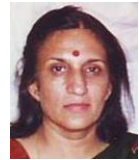

Dr. Kavita Marriya has retired as Head, Department of Clothing and Textiles, Govt. Home Science College, Chandigarh having a teaching experience of 34 years.

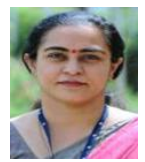

Dr. Radha Kashap is Head of the Deptt of Fashion \& Textile Technology and Member Secretary of Research Promotion Committee in The IIS University, Jaipur(Rajasthan),India. She has a teaching experience of 22 years. 